\title{
Research on the Impact Mechanism between Logistics Service Innovation and Online Customer Repurchase Intention
}

\author{
Dan Lin ${ }^{1, a}$, Rui Zhang ${ }^{2, b,{ }^{*}}$ \\ ${ }^{1}$ Room 411 Gangwu Building, No.350 Shixiang Road, Gongshu District, Hangzhou 310015 China \\ ${ }^{2}$ No.18 Xuezheng St., Zhejiang Gongshang University, Jianggan District, Hangzhou 310018 China \\ aattention31@163.coml, bzhangrui@zjgsu.edu.cn \\ ${ }^{*}$ Corresponding author
}

Keywords: Logistics service innovation, Repurchase intention, Order fulfillment quality, Customer satisfaction.

\begin{abstract}
Logistics service is an important part of online shopping consumers' perception and evaluation, which is also a critical factor for repurchase intention in E-commerce. This study aims to answer the basic question "how logistics service innovation influences online shopping customers" repurchase intention". Based on a theoretical presumption, this study selects four representative websites as research cases and includes product type as a moderator to analyze the impact of three dimensions of logistics service innovation: quickness, interaction and reliability on customer repurchase intention.9 hypotheses are proposed to construct a theoretical framework. The results find that logistics service quickness; interaction and reliability have a positive effect on customers repurchase intention through the mediating role of order fulfillment quality perception and customer satisfaction.
\end{abstract}

\section{Introduction}

As Internet and e-commerce constantly develops, the consumers' shopping preferences are turning to virtual networks from traditional physical stores. According to the published data of China Internet Network Information Center, up to December of 2014, the online shoppers in China have reached 361 million people, and the annual online retail sales have realized 2789.8 billion Yuan with an increase of $49.7 \%$ over the previous year, even the annual online penetration rate exceeded $10 \%$ for the first time. All data have shown that the number of online shoppers and the total amount of online shopping will continue to increase in the coming years.

With the constantly increasing of online shoppers, the competitions between online retailers become more and more intense, so how to keep old customers and attract new customers has become one of the most concerned questions for the internet retailers. Logistics is regarded as one of the three standards for assessing an online shop and an online shopping experience, which is also an important part for online retailers' reputation. Delivering goods to consumers relies on logistics services, which leads to a time and space delay [1], therefore, logistics service is a very important and indispensable part for the online shopping. However, the survey has found that customer complaints directly affected repurchase intention of online customers. How to improve the quality of logistics service has become a major event for e-commerce enterprises and online retailers. Some e-commerce enterprises improve logistics service through their self-established logistics, while others try to upgrade the logistics service quality in the test of pressure and opportunities, which certainly needs some logistics service innovations. Therefore, it is time to find out which innovation elements of logistics services will influence online repurchases, and how the mutual affecting relationship between them. This paper explores the relationship and action mechanism between logistics innovation factors and repurchase intention.

\section{Literature review}

\section{Overview of logistics service innovation theory}

In recent years, the domestic and overseas experts and scholars have become more and more experienced in the study of logistics service innovation. The overseas scholars mainly focus on the 
factors of logistics service innovation and how the service innovation creates customer values for the logistic enterprises and promote its competitive advantages [2-6]; while the domestic scholars pay more attention to the innovation model and path for logistics service [7-10].

Chapman et al. (2003) found that the factors of knowledge, technique, and relationship network all play a vital role for logistics service innovation [2]. Wagner (2008) pointed out that infrastructure, capital investment; employee training and education are all factors influencing the logistics enterprise service innovation in the study of German transportation [3]. Through exploratory multiple cases, Flint et al.(2011) have found that the deep cooperation and interaction of enterprises and customers not only make the enterprises to acquire new knowledge and find out innovation opportunities, but also identify the requirement changing, and provide more comprehensive logistics services for customers[4]. Richey et al. (2005) reckoned that the logistics service innovation can improve market efficiencies and competitive advantages, increase customers satisfaction and corporate profits by providing more customizing services. The research results indicated that, in a large corporate environment, logistics service innovation, corporation competitive advantages and performances have a positive correlation relationship [5]. Ja Shen Chen and Hung Tai Tsou (2012) believed that information technology capabilities and service process innovation can create higher customer values for the enterprise [6].

Basing on the characteristics of cloud logistics, Chinese scholar Wang Qifeng (2013) carried out researches on the realization of new model of logistic services and presented a cloud-based innovation model of logistics industry cluster services, including five kind of innovations of service concept, service organization, service organization, service process and service function[7]. Li Zengwei (2014) also proposed that the service innovation strategies of logistics enterprise could be broadly grouped into five areas: service interface innovation, cross-border innovation, logistics information platform innovation, technological innovation and process innovation [8]. In the innovation model study of logistics services base on service science, Xu Qi (2008) pointed out that service process is an enabler for the service innovation, and the process innovation enables the logistics process to be transferred from traditional few customers to the flexible systematic services [9]. Murat (2013) presented the same idea that the process innovation can affect customer perception for service quality, and create customer values [10]. Therefore, this study mainly takes the process innovation of logistics service as an entry point to explore the relationship between the logistics service and repurchase intention of online shoppers in the process innovation.

\section{Overview of repurchase intention theory}

For online retailers, the purchasing behaviors of online shopping by consumers can be divided into two phases: the initial purchase and repurchase. The retailers usually spend more time and efforts on attracting new customers, rather than retaining the existing customers [11]. Only $1 \%$ of online shoppers will repurchase the products in the same store [12]. However, retaining customers is an important factor for the enterprise to achieve competitive advantages. Therefore, how to keep the old customers and improve customer repurchase intentions has become one of the most concerned questions for online retailers.

Hellier et al. (2003) defined the repurchase intention as a consumer intention of repeatedly purchasing the same company's products based on previou shopping experiences [13]. According to the Information systems success model presented by DeLone \& McLean (2004), the indexes for assessing information system success include system quality, information quality, service quality, customer satisfaction, etc., and the customer satisfaction is a key indicator to assess information systems success [14]. Meng-Hsiang Hsu (2014) studied the determined factors of repurchase intentions on the basis of the success model of information system, and pointed out that satisfaction will directly affect consumers' re-selection and repurchase behaviors [15]. Changsu Kim et al. (2012) mainly studied the safety and availability of system quality, the diversity and liquidity of information quality, the rapidity and acceptability of service quality, the factors of which has close relations with utilitarian values and hedonic values of customer online shopping, and demonstrated that these factors make positive impact to the customer satisfaction and repurchase intentions through empirical analyses [16].

Taking considerations from customer values, domestic scholar Ni Hongyao (2013) reckoned that repurchase intention is a consumer's willingness in accordance with the utilitarian values and hedonic 
values experienced in the previous shopping, and deeply analyzed the effects to consumer's repurchase intention by the use quality, product quality, and service quality of the online store [17]. Hou Limin explored the influencing factors of customers' repurchase intentions taking the domestic barbershop business as the study object. The study found that customer satisfaction and customer perceived value have direct significant impacts on the repurchase intentions of haircut customers, while the different dimensions of barriers switching makes different effects to customers [18]. Through the study on the repurchase intentions of hotel customers, Zhu Yanhong found that the service quality plays the significant positive impacts upon the customer repurchase intentions, and generates indirect effects to the repurchase intentions through customers' satisfaction [19].

\section{Relations of logistics service innovation and repurchase intentions}

From the aforesaid studies of the domestic and overseas experts, we can see that the customer satisfaction is one of the important factors that affect repurchase intentions. Satisfaction is the perception on the differences of customer expectations and actual acceptances [20]. Oliver (1980) raised an expectation disconfirmation model and reckoned, during or after the consuming process, the customer will make a comparison on the actual experienced product or service performance with the previous purchase, while the differences of which is namely the inconsistency. If the actual performance is below expectation, then the customer will not be satisfied; if the actual performance meets or exceeds expectation, the customer will be satisfied [21]. McKinney et al. (2002) divided the expectation, performance, inconsistency and satisfaction into two aspects of information quality and system quality under internet environment and thus carried out the study, presented online customer satisfaction model based on the expectation inconsistency, and stressed that the satisfaction is an emotional state [22]. In the highly competitive e-commerce market, online retailers need to meet high quality of services to attract customers, and improve customer satisfaction for retaining their customers [23]. Nachiappan Subramanian et al. (2014) raised that consumer dissatisfaction will cause diverse effects to e-commerce enterprises, including loss of customers, poor site reputation, declining of brand values [24]. Lewin (2009) considered that customer satisfaction is an important source of competitive advantages, which may lead to customer loyalty and purchases [25]. Therefore, this study introduces the intermediary variable of customer satisfaction into the influences to customer repurchase intentions by the innovative logistics services, and investigates that whether the logistics service innovation acts on customer satisfaction and thereby affects repurchase intentions or not.

In addition, many domestic and overseas scholars have carried out the researches on the factors of affecting customer satisfaction. Liu et al. (2008) presented that information quality, website design, product attributes, trading capabilities, security, payment, delivery and customer services all have a significant effect on the satisfaction of online shoppers [26]. Besides, they stressed the importance of service delivery and customer services to the satisfactions of Chinese consumers. The logistics service scopes have a significant impact on customer satisfaction due to the geographical characteristics of China, and scattering distribution of customers, and these services depend on the number of transportation, storage locations, and distribution center [27]. Meanwhile, the logistics services are required to be changed with customer needs, for example, the parcel numbers of the approaching winter and summer vacations or holidays will be significantly greater than the amounts received in the usual days. Therefore, from the perspective of the logistics services, this paper introduces another intermediary variable, order fulfillment quality perception.

In order to complete an online shopping, customers need two aspects: generate an online order and complete an offline order, while the perception to online purchase value and repurchase intention are also originated from these two aspects [28]. Bienstock et al. (1997) carried studies from industrial market perspective and reckoned that the quality distribution can be measured from multiple dimensions, such as timeliness, goods availability, and order conditions [29]. But numerous studies indicated that the distribution quality dimensions presented by Bienstock et al. (1997) also apply to the network retails, and these dimensions can create customer repurchase intention. Parasuraman et al. (2005) stressed the importance of "fulfill" in order fulfillment, which namely is that the online retailers fulfill their commitments of orders distribution and goods available for customers [30]. Through the empirical analyses to online food retailing, Heim and Sinha (2001) found that the offline factors of on-time goods delivery, goods availability, ease of sales return all have important influences on repurchase intentions [31]. The studies of Rao et al. (2011) indicated that a bad delivery 
experience would increase customer's anxiety, and reduce customer satisfaction and repurchase frequency [32].

In summary, this study takes order fulfillment quality perception and customer satisfaction as two intermediate variables, thereby further explores the affecting relationships between the logistics service innovation and repurchase intentions of online consumers.

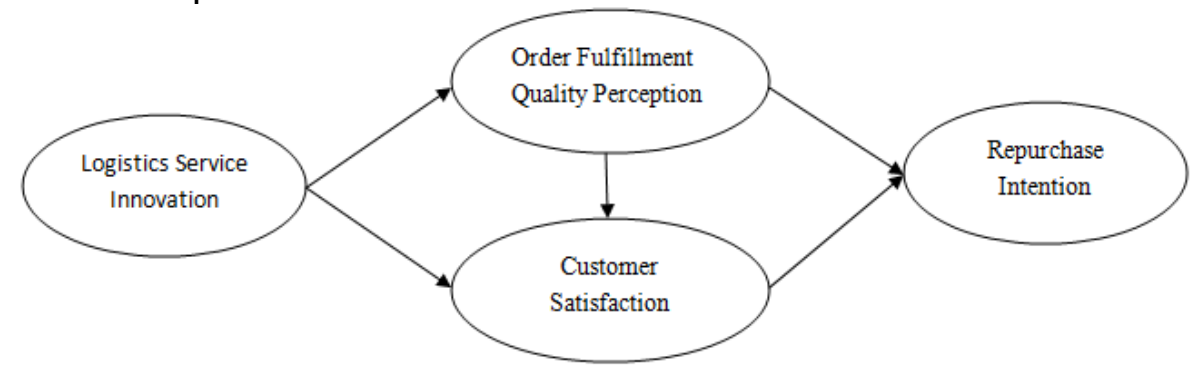

Fig.1 Hypothetical Model about the Impact of Logistics Service Innovation on Customer Repurchase Intention

\section{Exploratory cases study}

\section{Case selection}

For further exploring the influences to customer repurchase intentions by the different dimensions of logistics service innovation, this paper selects four representative e-commerce websites of recent years as samples, which are Taobao, Suning, Jingdong and Amazon. Meanwhile, the paper takes product type as a moderator variable, randomly selects a product in each e-commerce website, and explores how the logistics services to the same product provided in different stores will impact the satisfactions and repurchase intentions of online shoppers.

As early as the beginning of internet age, Nelson (1970) once divided products into two categories, search products and experience products [33]. Search products mean that the products information obtained from online retailers bring great values to the customers, who may accurately evaluate the products through this information. The search products are electronic/digital products, computers, etc.; experience products mean that the information obtained from online retailers by customers can not accurately and truly reflect the products' characteristics, and the products can be evaluated only after use in accordance with use conditions. The experience products are clothing, accessories, and so on.

Therefore, this study has selected Taobao clothing, digital products of Jingdong, household appliances of Suning and Amazon books, explored the various dimensions of logistics service innovation and made empirical analyses of the relationships between logistics service innovation and repurchase intentions of online shoppers through multiple cases.

\section{Data collection}

In order to improve research validity and reliability, this paper obtains information from multiple materials and aspects.

Tab.1 The Case of Taobao clothing

\begin{tabular}{lccccc}
\hline & Shop A & Shop B & Shop C & Shop D & Shop E \\
\hline Total Logistics score(Total 5.0) & 4.72 & 4.43 & 4.68 & 4.66 & 4.87 \\
Seller Delivery speed & Fast & Slow & Very fast & Fast & Fast \\
Seller attitude & Good & Not bad & Terrible & Very good & Very good \\
Logistics distributing speed & Fast & Slow & Fast & Slow & Fast \\
Return/Exchange speed & Fast & Cannot be returned & Slow & Slow & Fast \\
Courier attitude & Good & Good & Good & Good & Good \\
Logistics information renewal & Timely & Delayed & Timely & Delayed & Timely \\
Packaging & Intact & Broken & Intact & Intact & Intact \\
\hline
\end{tabular}

In each website, it selected hot selling products, and carried out deeply semi-structured researches from online retailers and online shoppers, whereby the interview-accepted online retailers have an average selling period of 5.89 years and generally have higher reputations. In addition, the paper has 
summarized the perception to logistics services and order fulfillment quality by selecting and viewing large amounts of valuable online shoppers' comments and real product pictures, and reflected the customer satisfactions and repurchase intentions relying on the direct evaluation of consumers.

Tab.2 The Case of Jingdong digital products (Hypothetical destination: Hangzhou, Order time: before Feb.25 18:00)

\begin{tabular}{lccc}
\hline & Jingdong & Store1 & Store2 \\
\hline Estimated arrival time & February 26 & March 3-March 9 & Before March 3 \\
Delivery attitude & Good & Bad & Good \\
Return speed & (including inspection) & (without inspection) & Fast \\
After-sale service & Fast & Very Slow & Good \\
Customer satisfaction & Good & Bad & $93 \%$ \\
degree(Total 100\%) & $96 \%$ & $88 \%$ & Strong \\
Repurchase intention & Strong & Weak & \\
\hline
\end{tabular}

Tab.3 The Case of Suning household appliances

\begin{tabular}{lccc}
\hline & Suning & Store1 & Store2 \\
\hline Delivery speed & Very fast & Fast & Fast \\
Courier attitude & Good & Good & Not good \\
Return speed & Slow & Very Slow & Slow \\
After-sale service & Good & Bad & Bad \\
Packaging & Intact & Intact & Deformed \\
Customer satisfaction & $96 \%$ & $90 \%$ & $88 \%$ \\
degree(Total 100\%) & Strong & Strong & Weak \\
Repurchase intention & & & \\
\hline
\end{tabular}

Tab.4 The Case of Amazon books

\begin{tabular}{|c|c|c|c|c|c|}
\hline & Amazon & Bookstore1 & Bookstore2 & Bookstore3 & Bookstore4 \\
\hline Delivery speed & Very fast & $\begin{array}{l}\text { Slow, } 2 \text { weeks } \\
\text { average }\end{array}$ & Slow & Slow & $\begin{array}{c}\text { Fast,2-3 } \\
\text { working days }\end{array}$ \\
\hline $\begin{array}{l}\text { Logistics information } \\
\text { renewal }\end{array}$ & Timely & Timely & Delayed & Delayed & Timely \\
\hline Packaging & $\begin{array}{l}\text { Wrapped in } \\
\text { wet }\end{array}$ & Intact & Intact & Broken & waterproof \\
\hline After-sale service & Good & Good & $\mathrm{Bad}$ & $\begin{array}{l}\text { Bad, cannot be } \\
\text { returned }\end{array}$ & Good \\
\hline $\begin{array}{l}\text { Customer satisfaction } \\
\text { degree(Total 5.0) }\end{array}$ & 4.3 & 4.35 & 4.25 & 4.15 & 4.4 \\
\hline Repurchase intention & Strong & Weak & Weak & Weak & Strong \\
\hline
\end{tabular}

\section{Case studies and research propositions}

According to the aforesaid cases and combing with other related theoretical studies, this paper summarizes various dimensions of logistics service innovation, analyzes the relations and causalities between various dimensions and order fulfillment quality, customer satisfaction and repurchase intention, and thus proposes corresponding propositions.

\section{Logistics service innovation}

Logistics service quickness. Fast goods delivery and after-sale return/exchange speed are all parts of the customer perceptions of logistics services [34]. It can be seen from the four tables that logistics distributing speed, seller delivery speed, goods return and exchange speed are the most important concerns for online shoppers. Besides, e-commerce websites all take the logistics services as an important part of customer evaluations. Lin (2007) reckoned that logistics service providers need to be prepared for the fast responses to customers requirements, including timely delivery, orders changing, cancellation, and goods return and exchange [35], because customers' perceptions to online shopping services mainly come from the timeliness and rapidity of delivering goods to the 
hands of customers [36]. It can be seen from Table 1 that the seller delivery speed, logistics distribution speed, and goods return and exchange speed are relatively faster than other 3 stores with higher logistics assessment scores, while store B not only presents a slow goods delivery speed, but also rejects to return, which greatly reduces the customers' satisfactions and wins less scores than other stores. From Table 4, we can also find that readers pay more attention to the book distribution speed. Amazon's own bookstore shows much faster distribution speed than other 4 book stores, even if there have been book package damages happened to Amazon store, the customers' repurchase intentions are still generally higher. The studies of Ha and Stoel (2009) showed that raising goods distribution speed, return and exchange speed can create good online shopping experiences for consumers, so as to promote the customers' perceptions to the online shopping hedonic values and order fulfillment [37]. While Kim et al (2012) carried out empirical researches and indicated that consumers' perceptions to the online shopping hedonic values are bringing a positive impact to customer satisfactions and further influencing the repurchase intentions of customers [16].

Through analyses, this paper proposed the following proposition:

H1.Logistics service quickness has a positive effect on order fulfillment quality perception.

H2.Logistics service quickness has a positive effect on customer satisfaction.

Logistics service interaction. Bilderbeek et al. (1998) once proposed the four-dimensional model of service innovation, mainly including service concept innovation, technological support innovation, customer interface innovation and service delivery system innovation, in which the customer interface innovation research occupied a large proportion. The dimension of customer interface innovation highlighted the involvement of customers, and pointed out that the service means and attitudes have close relationships with customers [38]. No customer, no service process occurs. Each service process requires the interaction and mutual effect of service providers and customers.

It can be seen from Table 1, the interaction factors between online retailers and customers include: service attitudes of sellers, courier attitudes and renewal of logistics information. Good service attitude and timely renewal speed of logistics information can not merely improve the customer satisfaction, but also win a good reputation for the enterprise. For example, in Table 1, the after-service of store A will help its customers to track the delivery, but store C leaves much to be desired. As a result, the logistics score of store A is higher than store C. Another example is provided in Table 2, where Jingdong self-support store provides home delivery services and support the payment after inspection, which wins more reputations and customer repurchase intentions comparing with store 1 who does not allow the inspection before payment. Therefore, this paper takes logistics service interactivity as an important dimension in the logistics service innovation and divides it into two parts, the information exchange and human interaction.

In the process of logistics services, the customers, online retailers, and logistics service providers have information exchanges. Yang Yongqing and Yu Benhai (2014) reckoned that the information service is an indispensable part of modern logistics, providing immediate information to customers: such as geographic location, order status, tracking information, arrival alerts, etc., which have become the important factors for logistics enterprises to improve their competitiveness [39]. Meanwhile, He Yaoyu, Lv Yongwei (2012) through empirical analyses, presented that the customer perceptions to the accuracy, timeliness, and easy understandability of the information provided by logistics service providers will significantly affect customer satisfactions [40]. The logistics information updating speed at Table 1 and the order status updating speed at Table 4 both have some impacts on customer satisfactions and repurchase intentions. On the other hand, the communication and interaction between customers and logistics service personnel also cannot be ignored. Zheng Bing (2008), in the study of antecedents of influencing customer satisfactions, noted that the courier communication quality means that the problem-solving abilities, related experiences, and communication attitudes to customers of the service stuffs who are responsible for logistics services will affect order fulfillment quality perceptions and satisfaction[41].

Through analyses, this paper proposed the following proposition:

H3.Logistics service interaction has a positive effect on order fulfillment quality perception.

H4.Logistics service interaction has a positive effect on customer satisfaction.

Logistics service reliability. Long \& McMellon (2004) and Parasuraman et al. (2005) reckoned, for online retailers, the service reliability and fast-respondability are more important than the usability and aesthetic property of products[42][30]. Olgun Kitapcia et al. (2014), through empirical studies, presented that the service reliability in medical field will give a positive impact on patient 
satisfaction [43]. Chinese scholar Wang Wei (2011) took the goods delivery timeliness, the soundness of received goods, the accuracy of processing orders, and the response time for online shopping as four areas of the customer perceptions to service reliability, and indicated that the service reliability have a significant positive impact on customer satisfactions through empirical researches[44].

It can be seen from Table 3, the packaging conditions for some household appliances and other similar products with higher values are an important part of customer evaluation on logistics services. For example, the packaging of Suning self-supported store and specialty store 1 are both very complete, but specialty store 2 have been involved with damaged packaging cases, causing troubles to its customers, while at the same time bringing negative impacts on its reputation and effectiveness. Meanwhile, according to the announced consumer complaints by State Post Bureau, the total consumer complaints of January, 2015 are 73,849 pieces. The involved postal service issues are 2793 pieces, occupying $3.8 \%$ of the total amounts; the involved courier business problems are 71,056 pieces, occupying $96.2 \%$ of the total amounts. In the involved issues of delivery business, the effective complaint pieces of delivery service issues are 9960 pieces, occupying 36.7\%; the express delay issues are 6685 pieces, occupying 24.7\%; the effective appeals due to express losses are 7249 pieces, occupying $26.7 \%$; the involved issues of express damaging are 1819 pieces, occupying for $6.7 \%$, etc. Therefore, online retailers and logistics companies still need to raise their attentions on the logistics service reliability.

Through analyses, this paper proposed the following proposition:

H5.Logistics service reliability has a positive effect on order fulfillment quality perception.

H6.Logistics service reliability has a positive effect on customer satisfaction.

\section{Perceptions of order fulfillment quality, customer satisfactions and repurchase intentions}

It can be seen from each case of this study, the customer's perceptions to orders will directly affect customer satisfactions and comments to online retailers, and further affect the repurchase intentions. As shown in Table 1, the logistics scores for each store are originated from the customer perceptions to the seller delivery speed, seller service attitude, logistics distribution speed, goods return and exchange speed, courier attitude, logistics information renewal, and the extent of merchandise packaging, which is namely the perception to the order fulfillment quality. It can be seen from Table 2, Table 3 and Table 4, once the customer generates a strong perception to order, thinking the order can be highly fulfilled, then whose satisfaction to the online retailer will be continually increased and thereupon the repurchase intention will be increased.

Therefore, basing on the above analyses and theoretical presuppositions (Figure 1), this paper proposes the proposition to the relationships between the order fulfillment quality, customer satisfactions, and online shopper repurchases intentions as followings:

H7.Order fulfillment quality perception has a positive effect on online customer repurchase intention.

H8.Order fulfillment quality perception has a positive effect on customer satisfaction.

H9.Customer satisfaction has a positive effect on online customer repurchase intention.

\section{Conclusions and prospects}

In summary, through the researches on the cases of four representative e-commerce websites, this paper studies the impacts to online shoppers repurchase intentions generated by logistics service innovation, deeply analyzes three dimensions of logistics service innovation: logistics service quickness, logistics service interaction and logistics service reliability, notes that order fulfillment quality perception and customer satisfaction are the key mediating variable for the logistics service innovation to affect the repurchase intentions of online customers, and establishes a theoretical model of the logistics service innovation and the repurchase intentions (as shown in Figure 2). The paper presents that the quickness, interaction and reliability of logistics services are able to improve order fulfillment quality perceptions and customer satisfactions, so as to enhance the repurchase intentions of online consumers.

For the future researches, the author will further carry out empirical researches on the theoretical model to broaden the range of samples, deeply discuss the affecting relations and associating extents 
between each dimension by the means of questionnaire surveys, and also take the studying methods of factor analyses, correlation analyses, structural equation and others into consideration, more specifically explaining the mutual impacting conditions of various dimensions of logistics service innovation, order fulfillment quality perception, and customer satisfaction, which will lead to greater practical significance for e-commerce enterprises.

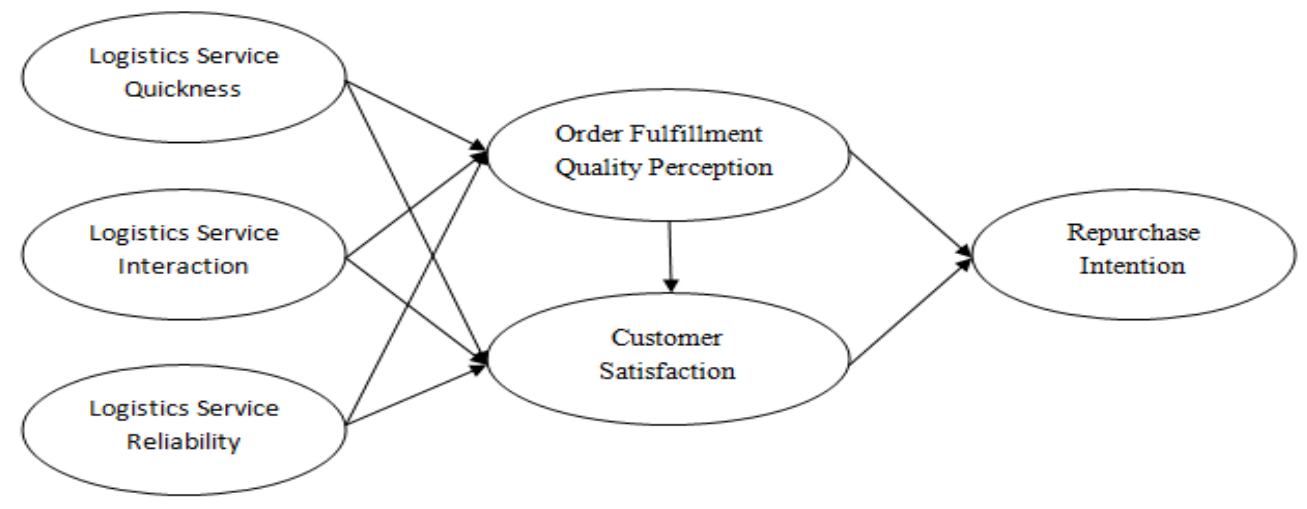

Fig.2 Theoretical Model about the Impact of Logistics Service Innovation on Customer Repurchase Intention

\section{Acknowledgment}

It is a project supported by Natural Science Foundation of Zhejiang Province of China (No: LY15G020008), and Modern Business Circulation System Construction Collaborative Innovation Center \& Contemporary Business and Trade Research Center of Zhejiang Gongshang University (No: 14SMXY01ZD).

\section{References}

[1] JIN Linghua, The Relationship between Logistics Service Quality and Online customer Loyalty [J]. Logistics Engineering and management, 2013(35):117-120.

[2] Chapman R. L.,Soosay C.,Kandampully J.Innovation in logistic services and the new business model[J]. International Journal of Physical Distribution \& Logistics Management, 2003, 33(7):630-650.

[3] Wagner S.M.Innovation management in the German transportation industry [J].Journal of Business Logistics, 2008, 29(2):215- 232.

[4] Flint D.J.,Larsson E.,Gammelgaard B.Logistics innovation: A customer value-oriented social process[J].Journal of Business Logistics,2011,26(1):113-147.

[5] Richey R.G.,Genchev S.E.,Daugherty P.J.The role of resource commitment and innovation in reverse logistics performance[J].International Journal of Physical Distribution \& Logistics Management,2005, 35(3/4):233-257.

[6] Ja Shen Chen, Hung Tai Tsou. Performance effects of IT capability, service process innovation, and the mediating role of customer service[J].Journal of Engineering and Technology Management, 2012(29):71-94.

[7] WANG Qifeng, Study on Innovative Service of Logistics Industrial Clusters Based on Cloud Logistics [J].Logustics Sci-Tech, 2013, 32(2):24-26.

[8] LI Zengwei, The Motivation Analyses and Methods Research on the Logistics Service Innovation [J]. Logustics Sci-Tech, 2014(5):65-67. 
[9] XU Qi,Study on Logistics Service Innovation Mode Based on Service Science[J]. Science \& Technology Progress and Policy, 2008(04):55-58.

[10] Murat Yaslioglu,Burcu Ozge Ozaslan Caliskan,Omer Sap.The role of innovation and perceived service quality in creating customer value: a study on employees of a call center establishment[J]. Procedia - Social and Behavioral Sciences, 2013(99):629-635.

[11] Yixiang Zhang,Yulin Fang,Kwok-Kee Wei,Elaine Ramsey,Patrick McCole,Huaping Chen, Repurchase intention in $\mathrm{B} 2 \mathrm{C}$ e-commerce-A relationship quality perspective[J], Information \& Management 2011(48):192-200.

[12] S. Gupta, K. Hee-Woong. The moderating effect of transaction experience on the decision calculus in online repurchase [J].International Journal of Electronic Commerce, 2007, 12(1):127-158.

[13] Hellier P., Geursen G., Carr R., Rickard J. Customer repurchase intention: a general structural equation model [J]. European Journal of Marketing, 2003, 37(11/12):1762-1800.

[14] DeLone W.H., McLean E.R. Measuring e-commerce success: Applying the DeLone W.H. \& McLean E.R. Information systems success model [J].International Journal of Electronic Commerce, 2004, 9(1), 31-47.

[15] Meng-Hsiang Hsu,Chun-Ming Chang, Kuo-Kuang Chu,Yi-Jung Lee. Determinants of repurchase intention in online group-buying:The perspectives of DeLone \& McLean IS success model and trust[J]. Computers in Human Behavior 2014(36):234-245.

[16] Changsu Kim,Robert D.Galliers,Namchul Shin,Joo-Han Ryoo,Jongheon Kim. Factors influencing Internet shopping value and customer repurchase intention [J]. Electronic Commerce Research and Applications 11(2012):374-387.

[17] NI Hongyao, Empirical Study of Consumer Purchase Factors Based on Structural Equation Model in B2C E-commerce [J]. Consumer Economics, 2013(03):60-64.

[18] HOU Limin, JIN Quan, MA Hong, Research on the Influence Factors and Relationship of Customer Loyalty in Service Industry[J].Guoji Shangwu Yanjiu,2013(34): 88-96.

[19] ZHU Yanhong, Study on the Factors of Hotel Customer Repurchase Intention [D].Zhejiang University, 2008.

[20] Geng X.\&Chu X. A new importance-performance analyses approach for customer satisfaction evaluation supporting PSS design [J]. Expert Systems with Applications, 39(2012):1492-1502.

[21] Oliver R. L.A cognitive model of the antecedents and consequences of satisfaction decisions [J]. Journal of Marketing Research, 1980, 17(4):460-469.

[22] McKinney V.,Yoon K.,\&Zahedi F.M.The measurement of web-customer satisfaction: An expectation and disconfirmation approach[J].Information Systems Research,2002,13(3):296-315.

[23] Tan K., Pawitra T.Integrating SERVQUAL and Kano's model into QFD for service excellence development [J]. Managing Service Quality, 2001, 11(6):418-433.

[24] Subramanian N.,Gunasekaran A.,Yu J.,Cheng J.,Ning K.Customer satisfaction and competitiveness in the Chinese e-retailing: structural equation modeling (SEM)approach to identify the role of quality factors[J].Expert Syst. Appl. 2014, 41(1)69-80.

[25] Lewin J.E.Business customer's satisfaction: what happens when suppliers downsize [J]. Ind.Mark.Manage. 2009, 38(3):283-299.

[26] Liu X., He M., Gao F.\&Xie P.An empirical study of online shopping customer satisfaction in China: A holistic perspective[J]. International Journal of Retail and Distribution Management, 2008, 36(11):919-940. 
[27] Du F.,Evans G.W..Abi-objective reverse logistics network analyses for post-sale service [J]. Comput.Oper.Res., 2008(35):2617-2634.

[38] Yun Kyung Cho, Creating customer repurchase intention in Internet retailing: The effects of multiple service events and product type[J]. Journal of Retailing and Consumer Services, 2015(22):213-222.

[29] Bienstock,C.C.,Mentzer,J.T.,Bird,M.M.Measuring physical distribution service quality[J]. Acad.Mark.Sci., 1997,25(1):31-44.

[30] Parasuraman A.,Zeithaml V.A.,Malhotra A.E-S-QUAL: amultiple-item scale for assessing electronic service quality[J].Serv.Res., 2005,7(3):213-233.

[31] Heim G.R.,Sinha K.K.Operational drivers of customer loyalty in electronic retailing: an empirical analyses of electronic food retailers[J].Manuf.Serv.Oper.Manag., 2001 (3):264-271.

[32] Rao S.,Griffis S.E.,Goldsby T.J.Failure to deliver Linking online order fulfillment glitches with future purchase behavior[J].Oper.Manag.,2011,29(7):692-703.

[33] Nelson P.Informationandconsumerbehavior [J].Polit.Econ.1970, 78(2), 311-329.

[34] Khalifa M.,Liu M.Online consumer retention: contingent effects of online shopping habit and online shopping experience[J]. European Journal of Information Systems, 2007, 16(6):780-792.

[35] Lin H.The impact of website quality dimensions on customer satisfaction in the B2C e-commerce context [J]. Total Quality Management, 2007, 18(4):363-378.

[36] Comegys, C., Hannula, M., and Vaisanen, J. Effects of consumer trust and risk on online purchase decision-making: a comparison of Finnish and United States students [J]. International Journal of Management, 2009, 26(2):295-308.

[37] Ha S. and Stoel L. Consumer e-shopping acceptance: antecedents in a technology acceptance model [J]. Journal of Business Research, 2009, 62(5):565-571.

[38] Bilderbeek Rob,Hertog Pim Den,Marklund Goran,et al.Service Innovaton:Knowledge Intensive Business Services(KIBS) As Co-producers of Innovation[R].Netherlands: NO Center for Technology and Policy Studies,SI4S Synthesis Papers,SI4S S3 Report,1998:10-24.

[39] YANG Yongqing, YU Benhai, Empirical Analyses of Online Consumers' Post-purchase Behavior Based on Logistics Service [J], Chinese Journal of Management,2014,(3):434-448.

[40] HE Yaoyu, LV Yongwei, The Practical Research on the Influencing Factors of Logistic Service Quality and Customer Loyalty[J], China Business and Market,2012,(7):79-82.

[41] ZHENG Bing,DONG Dahai,JIN Yufang, Research on Antecedents of Customer Satisfaction for the Third Logistics:Customer Based [J], Journal of Indu strial Engineering/Engineering Management, 2008(2): 51-57.

[42] Long, M., \& McMellon, C. Exploring the determinants of retail service quality on the internet [J]. Journal of Services Marketing, 2004(18):78-90.

[43] Olgun Kitapci,Ceylan Akdogan,İbrahim Taylan Dortyol.The Impact of Service Quality Dimensions on Patient Satisfaction, Repurchase Intentions and Word-of-Mouth Communication in the Public Healthcare Industry[J].Procedia - Social and Behavioral Sciences, 2014(148) 161-169.

[44] WANG Wei, The relationship between logistics service quality and online purchasing behavior in C2C e-commerce [J]. Economic Forum.2011, (1):161-164. 